\title{
Silica cycling in the ultra-oligotrophic eastern Mediterranean Sea
}

\author{
M. D. Krom ${ }^{1,2}$, N. Kress ${ }^{3}$, and K. Fanning ${ }^{4}$ \\ ${ }^{1}$ Charney School of Marine Sciences, Haifa University, Haifa, Israel \\ ${ }^{2}$ School of Earth and Environment, Leeds University, Leeds, UK \\ ${ }^{3}$ National Institute of Oceanography, Israel Oceanographic Limnological Research, Tel Shikmona, Haifa POB 8030, Israel \\ ${ }^{4}$ College of Marine Science, University of South Florida, 140 Seventh Avenue South, St. Petersburg, FL 33704, USA
}

Correspondence to: M. D. Krom (m.d.krom@leeds.ac.uk)

Received: 31 January 2014 - Published in Biogeosciences Discuss.: 18 March 2014

Revised: 24 June 2014 - Accepted: 26 June 2014 - Published: 12 August 2014

\begin{abstract}
Although silica is a key plant nutrient, there have been few studies aimed at understanding the Si cycle in the eastern Mediterranean Sea (EMS). Here we use a combination of new measurements and literature values to explain the silicic acid distribution across the basin and to calculate a silica budget to identify the key controlling processes. The surface water concentration of $\sim 1 \mu \mathrm{M}$, which is unchanging seasonally across the basin, was due to the inflow of western Mediterranean Sea (WMS) water at the Straits of Sicily. It does not change seasonally because there is only a sparse population of diatoms due to the low nutrient ( $\mathrm{N}$ and P) supply to the photic zone in the EMS. The concentration of silicic acid in the deep water of the western Ionian Sea $(6.3 \mu \mathrm{M})$ close to the S Adriatic are an of formation was due to the preformed silicic acid $(3 \mu \mathrm{M})$ plus biogenic silica ( $\mathrm{BSi}$ ) from the dissolution of diatoms from the winter phytoplankton bloom $(3.2 \mu \mathrm{M})$. The increase of $4.4 \mu \mathrm{M}$ across the deep water of the EMS was due to silicic acid formed from in situ diagenetic weathering of aluminosilicate minerals fluxing out of the sediment. The major inputs to the EMS are silicic acid and BSi inflowing from the western Mediterranean $\left(121 \times 10^{9} \mathrm{~mol} \mathrm{Si} \mathrm{yr}^{-1}\right.$ silicic acid and $16 \times 10^{9} \mathrm{~mol} \mathrm{Si} \mathrm{yr}^{-1} \mathrm{BSi}$ ), silicic acid fluxing from the sediment $\left(54 \times 10^{9} \mathrm{~mol} \mathrm{Si} \mathrm{yr}^{-1}\right)$ and riverine $\left(27 \times 10^{9} \mathrm{~mol} \mathrm{Si} \mathrm{yr}^{-1}\right)$ and subterranean groundwater $\left(9.7 \times 10^{9} \mathrm{~mol} \mathrm{Si} \mathrm{yr}^{-1}\right)$ inputs, with only a minor direct input from dissolution of dust in the water column $\left(1 \times 10^{9} \mathrm{~mol} \mathrm{Si} \mathrm{yr}^{-1}\right)$. This budget shows the importance of rapidly dissolving $\mathrm{BSi}$ and in situ weathering of aluminosilicate minerals as sources of silica to balance the net export of silicic acid at the Straits of Sicily. Future measure-
\end{abstract}

ments to improve the accuracy of this preliminary budget have been identified.

\section{Introduction}

Silicon is a key plant nutrient in the global ocean. There have been many studies describing the oceanic silica cycle (e.g. Benitez-Nelson et al., 2007; Brzezinski et al., 2011; DeMaster, 1981; Dugdale and Wilkerson, 1998; Nelson et al., 1995; Ragueneau et al., 2000). However, there have been few studies examining the unusual distribution of silica in the eastern Mediterranean Sea (EMS) (Crombet et al., 2011; Kress and Herut, 2001; Ribera d'Alcalà et al., 2003; Schink, 1967). The depth distribution of silicic acid (SA) in the global ocean is typically low in the photic zone with an increase in concentration with depth. This feature is generally interpreted as silicic acid uptake in the photic zone by diatoms (or other silica containing plankton) that sink where they dissolve and increase silicic acid concentration with depth (Armbrust, 2009). However there are problems with this simple explanation in the EMS because over large areas there are very low diatom numbers (Ignatiades et al., 2009; Psarra et al., 2000), assumed to be because the nutrient supply to the photic zone is below the threshold required for diatom growth. While Crombet et al. (2011) found evidence for what they describe as a "deep glass forest" of diatoms at the bottom of the deep chlorophyll maximum/upper nutricline across the Western Mediterranean Sea (WMS), they only found diatoms in the EMS at locations where there was a locally increased nutrient supply to the photic zone (Straits of Sicily, Mediterranean front and Cyprus eddy). Elsewhere, small non-silicate 
phytoplankton, more efficient in utilising nutrients in limited supply, dominate (Huete-Ortega et al., 2011; Siokou-Frangou et al., 2010).

The concentration and seasonal cycle of dissolved silicic acid in the EMS is unusual compared to other areas of the global ocean. In the EMS silicic acid concentrations in the photic zone are generally relatively constant at $\sim 1 \mu \mathrm{mol} \mathrm{Si} \mathrm{kg}{ }^{-1}$ and do not vary seasonally (Kress and Herut, 2001; Krom et al., 1992), which contrasts with the situation in many areas of the ocean, including the western Mediterranean (Brzezinski and Nelson, 1995; Marty et al., 2002). Silicic acid increases with depth with a sharp siliciacline from 200 to $\sim 1000 \mathrm{~m}$. The maximum concentrations in the deep waters of the EMS are very low $\left(6-11 \mu \mathrm{mol} \mathrm{Si} \mathrm{kg}{ }^{-1}\right)$ (Kress and Herut, 2001; Pujo-Pay et al., 2011), compared to $17-49 \mu \mathrm{mol} \mathrm{Si} \mathrm{kg}^{-1}$ in the $\mathrm{N}$ Atlantic (Bainbridge, 1981), $80 \mu \mathrm{mol} \mathrm{Si} \mathrm{kg}{ }^{-1}$ in the S Atlantic and $\sim 120 \mu \mathrm{mol} \mathrm{Si} \mathrm{kg}^{-1}$ in the N Pacific (Chester, 2002).

There is a systematic increase in dissolved silicic acid across deep waters of the EMS from $6.3 \mu \mathrm{mol} \mathrm{Si} \mathrm{kg}{ }^{-1}$ in the western Ionian Sea close to the major source of Adriatic deep water (ADW) in the southern Adriatic to $\sim 10.7 \mu \mathrm{mol} \mathrm{Si} \mathrm{kg}{ }^{-1}$ in the eastern Levantine basin in the direction of the deepwater circulation and increased water age (Roether and Schlitzer, 1991; Schlitzer et al., 1991). This eastwards increase is relatively much larger for silicic acid than that for nitrate or phosphate (Kress et al., 2003, 2011). Recently, as a result of the Eastern Mediterranean Transient (EMT) event, younger and denser water of Aegean origin with lower silicic acid content was introduced into the Ionian and Levantine deep layers (Roether et al., 1996, 2007). This reduced the concentration at depth and formed a pronounced mid-depth silicic acid maximum (Kress et al., 2003, 2011).

A key difference between the EMS and many other areas of the global ocean is that the annual phytoplankton bloom is in winter, at the same time as deep and intermediate waters are formed (Krom et al., 2013). Siokou-Frangou et al. (2010) describe increases in diatoms in February-March in the southern Adriatic, which is the source for deep water to the EMS (Adriatic deep water), and in the Cretan Sea, which is the source of Cretan Sea Outflow Water during the transient event. It is thus likely that when waters convect down from the photic zone, they contain diatom frustules made from opaline $\mathrm{Si}$ (BSi) as well as "preformed" silicic acid. In almost all areas of the global ocean, silicic acid is undersaturated and BSi tends to dissolve (DeMaster, 2004; Fanning and Schink, 1969). However this process is likely to be faster in the relatively "warm" and strongly undersaturated deep waters of the EMS.

Nutrient budgets have been used extensively to understand biogeochemical cycling processes in the eastern Mediterranean, partly because the system is well constrained with marine inputs and outputs occurring through the relatively narrow Straits of Sicily (Bethoux et al., 1992; Krom et al., 2004, 2010; Ribera d'Alcalà et al., 2003). The nutrient bud- get for $\mathrm{N}$ and $\mathrm{P}$ has been used to explain why the EMS has an unusually high nitrate : phosphate ratio $(28: 1)$ in deep water (Krom et al., 1991) and predict that there would be very limited $\mathrm{N}_{2}$ fixation (Krom et al., 2004), which was subsequently confirmed by field measurements (Ibello et al., 2010; Yogev et al., 2011). Only two silica budgets have been attempted in the Mediterranean. The first by Schink (1967) found a net loss of silicic acid at the Straits of Gibraltar and assumed this was balanced by riverine input of dissolved silicic acid, though noting that riverine flux data were very sparse at the time of his study. The second budget was carried out for the eastern Mediterranean by Ribera d'Alcala et al. (2003), who found that the net flux of dissolved silicic acid out of the basin $\left(150-250 \times 10^{9} \mathrm{~mol} \mathrm{Si} \mathrm{yr}^{-1}\right)$ was far higher than the best estimates available for the inputs from rivers and other sources. They were unable to explain the reason for this pattern and hypothesised that the missing term in the silica budget might reflect some change in the terrestrial inputs and suggested that further work was needed to investigate this obvious mismatch. However these budgets were carried out only for dissolved silicic acid and did not include estimates for particulate biogenic opaline silica (BSi).

An addition and potentially important source of silicic acid to the EMS is the in situ chemical weathering aluminosilicate minerals (Fanning and Schink, 1969; Mackenzie and Garrels, 1965). This phase is recognised and measured as lithogenic $\mathrm{Si}$ (LSi) (Koning et al., 2002). This is likely to represent an important source of "new" silica to the water column in the EMS where there is a relatively large flux of Saharan dust which consists mainly of clay minerals and aluminosilicates (Venkatarathnam and Ryan, 1971) and the background concentration of silicic acid is equally low.

In this study we aim to explain the distribution and concentration of silicic acid in the eastern Mediterranean water column. Data from cross-basin water column transects are combined with previously unpublished porewater data to determine the importance of dissolved silicic acid fluxing from the sediment as a source to the deep water. A total silica budget for the EMS basin including both silicic acid and silica derived from particulate matter (BSi and chemical weathering of aluminosilicate minerals (LSi)) is calculated. Using this silica budget we identify the most important processes affecting the silica cycle and suggest where detailed measurements are required to improve the accuracy of the silica budget.

\section{Materials and methods}

\subsection{Silicic acid in the water column}

Data on the silicic acid distribution in the eastern Mediterranean were collected during several oceanographic cruises (Kress et al., 2003, 2014; Kress and Herut, 2001). Briefly, continuous profiles of pressure, temperature, 
Table 1. Sampling stations, bottom silicic acid [SA] concentrations from hydrocasts in the water column of the deep EMS (Ionian and Levantine basins), and measurements from the upper layers of gravity cores used in calculations of diffusion gradients sampled during the TR-171 cruise of the R/V Trident in September 1975 (Jones, 1977).

\begin{tabular}{|c|c|c|c|c|c|c|c|c|}
\hline $\begin{array}{l}\text { Stn } \\
\text { no. }\end{array}$ & Location & & $\begin{array}{l}\text { Depth } \\
\text { (m) }\end{array}$ & $\begin{array}{l}\text { Core } \\
\text { no. }\end{array}$ & $\begin{array}{l}\text { Bottom [SA] } \\
(\mu \mathrm{M})\end{array}$ & $\begin{array}{l}\text { Upper slice } \\
\text { thickness }(\mathrm{cm})\end{array}$ & $\begin{array}{l}\text { Porewater }[\mathrm{SA}] \text { in } \\
\text { upper slice }(\mu \mathrm{M})\end{array}$ & $\begin{array}{l}\text { Gradient } \\
\left(\mu \mathrm{Mcm}^{-1}\right)\end{array}$ \\
\hline 27 & $35^{\circ} 24.1^{\prime} \mathrm{N}$ & $17^{\circ} 19.3^{\prime} \mathrm{E}$ & 3800 & Core 6 & & 0.5 & 15.0 & 22.8 \\
\hline 27 & $35^{\circ} 24.0^{\prime} \mathrm{N}$ & $17^{\circ} 19.9^{\prime} \mathrm{E}$ & 3800 & Cast 6 & 9.3 & & & \\
\hline 29 & $34^{\circ} 16.9^{\prime} \mathrm{N}$ & $19^{\circ} 32.0^{\prime} \mathrm{E}$ & 3590 & Cast 7 & $9.2^{\mathrm{a}}$ & & & \\
\hline 30 & $34^{\circ} 25.5^{\prime} \mathrm{N}$ & $20^{\circ} 07.9^{\prime} \mathrm{E}$ & 2770 & Core 7 & & 0.5 & 20.0 & 43.2 \\
\hline 34 & $34^{\circ} 00.3^{\prime} \mathrm{N}$ & $23^{\circ} 10.9^{\prime} \mathrm{E}$ & 2535 & Cast 8 & 10.2 & & & \\
\hline 37 & $33^{\circ} 50.0^{\prime} \mathrm{N}$ & $26^{\circ} 00.6^{\prime} \mathrm{E}$ & 2720 & Core 8 & & 1.0 & 30.9 & 41.4 \\
\hline 37 & $33^{\circ} 48.0^{\prime} \mathrm{N}$ & $26^{\circ} 00.4^{\prime} \mathrm{E}$ & 2755 & Cast 9 & & & & \\
\hline \multirow[t]{2}{*}{40} & $35^{\circ} 41.2^{\prime} \mathrm{N}$ & $25^{\circ} 18.4^{\prime} \mathrm{E}$ & 916 & Core 10 & 8.5 & 1.0 & 35.2 & 53.4 \\
\hline & & & & & & & Average $^{b}$ & 35.8 \\
\hline
\end{tabular}

${ }^{a}$ Bottom [Si] was assumed to be the same as at nearby station 29. ${ }^{\mathrm{b}}$ Average does not include core 10 because it was in shallower water (916 $\left.\mathrm{m}\right)$, in the Aegean Sea, north of the island of Crete.

salinity, dissolved oxyge and fluorescence were performed with a Sea-Bird SBE 911 plus CTD system, interfaced to a SBE Carousel equipped with Niskin bottles. Water samples for silicic acid determination were collected in $15 \mathrm{~mL}$ acidwashed plastic scintillation vials and immediately frozen. In the laboratory, silicic acid was determined using a segmented flow Technicon AutoAnalyzer AA-II or Seal Analytical AA3 using the reaction with ammonium molybdate in an acidic medium to form silicomolybdic acid which is reduced to the molybdenum blue with stannous chloride, and the absorption is measured at $820 \mathrm{~nm}$ (Kress and Herut, 2001; Krom et al., 1991). The precision of these determinations ranged from 1 to $5 \%$ depending on the concentration range.

Published data from the Meteor M5/6 cruise in 1987 (Nellen et al., 1996; Schlitzer et al., 1991) were obtained from the Israel Oceanographic and Limnological Research (IOLR) Marine Data Center (http://isramar.ocean.org. il/isramar2009/default.aspx).

\subsection{Silicic acid in the water column and porewaters sampled in 1975 (Jones, 1977)}

The samples used for porewater flux determinations were obtained on cruise TR-171 of the R/V Trident during September 1975. The stations presented in this study were those stations in the Ionian and Levantine basins of the eastern Mediterranean (Table 1). Gravity cores were taken with a benthos gravity corer. The cores were capped and stored upright for at least $24 \mathrm{~h}$ in a cold room at in situ bottom temperatures before squeezing.

Inside the cold room, cores were sampled every $0.5 \mathrm{~cm}$ to a depth of $10 \mathrm{~cm}$ and then every $10 \mathrm{~cm}$ to the end. Each extruded sediment sample was placed in a Reeburgh type squeezer (Reeburgh, 1967) and the porewater allowed to drip directly into the storage bottle after 0.45 micron filtration. Details of the actual squeezer as used in four banks of five squeezers are given in Jones (1977) and Kruikov and Manheim (1982). The porewater samples were sealed in clean polyethylene bottles with parafilm, and then capped and stored in the dark at room temperature for subsequent analysis. The sediment squeezer cake was sealed in a WhirlPak bag for subsequent porosity determination.

Hydrocasts were taken with $5 \mathrm{~L}$ Niskin bottles. The bottom sample at all stations was within $20 \mathrm{~m}$ of the sediment-water interface. Water samples were taken for dissolved oxygen, salinity and dissolved silicic acid determinations. Samples taken for salinity and oxygen determinations were processed on board ship. Both hydrocast and porewater samples were stored in clean polypropylene bottles in the dark and were analysed for silicic acid within 2 weeks of returning from the cruise. The automated method for the silicic acid determinations was a modification of the method of Truesdale and Smith (1976) using ascorbic acid instead of tin (II) chloride to reduce molybdosilicic acid. Precision of three replicate hydrocast samples $(n=4)$ was $0.1 \mu \mathrm{M}(1.2 \%)$. The measured concentration in the water column during the TR-171 cruise $\left(\sim 9 \mu \mathrm{mol} \mathrm{Si} \mathrm{kg}{ }^{-1}\right)$ was similar in magnitude to subsequent water column measurements across the EMS.

Porosity was calculated from the calculated volume of the porewater/volume of the bulk sediment using a density for seawater of 1.028 and an average sediment density of $2.7 \mathrm{~g} \mathrm{~cm}^{-3}$

Nomenclature: in this text we use "silica" (i.e. all silica phases) for the total budget, "biogenic silica" (BSi) for the particulate opaline phase and "silicic acid" for dissolved silicate. In addition we use units of $\mu \mathrm{mol} \mathrm{Si} \mathrm{kg}{ }^{-1}$ for the dissolved silicic acid phases except in calculations where we use for simplicity $\mu \mathrm{mol} \mathrm{Si} \mathrm{L}{ }^{-1}$. We assume the difference between these two units makes no significant difference to the various budget and flux calculations being carried out. 


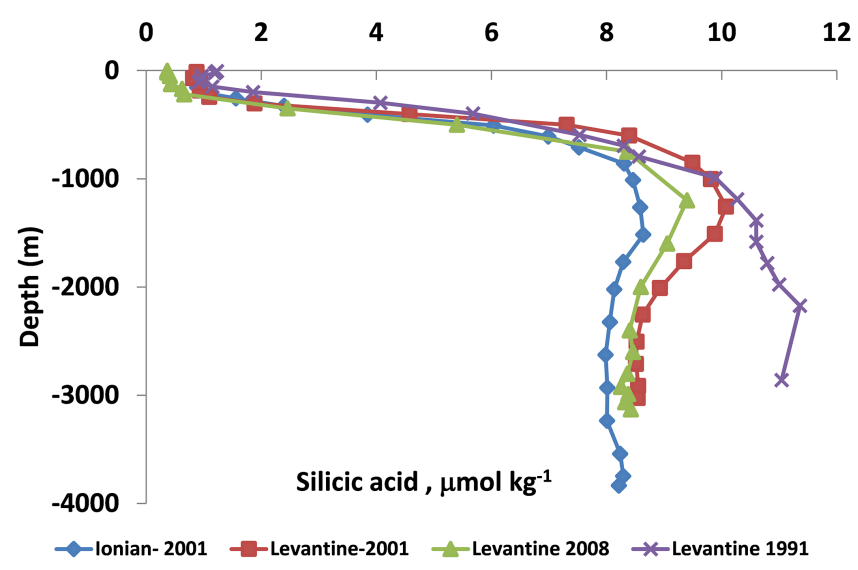

Figure 1. Typical silicic acid profiles in the Levantine basin prior to the effect of the EMT event (1991) and after the EMT event (2001 and 2008). A profile in the Ionian (2001) is included for comparison. Data from Kress et al. (2003, 2014).

\section{Results}

\subsection{Silicic acid in the water column across the basin}

The surface waters of the offshore EMS generally have concentrations of $\sim 1 \mu \mathrm{mol} \mathrm{Si} \mathrm{kg}{ }^{-1}$ silicic acid throughout the photic zone (Figs. 1-2) (Krasakopoulou et al., 1999; Kress and Herut, 2001; Lascaratos et al., 1999; Yilmaz and Tugrul, 1998). Until 1990, the concentration of SA increased with depth from the base of the photic zone to the bottom, except in the western Ionian Sea. There, a maximum silicic acid layer $\left(8.3 \mu \mathrm{mol} \mathrm{Si} \mathrm{kg}{ }^{-1}\right)$ was found at $1200 \mathrm{~m}$ depth due to the intrusion of newly added ADW at depth toward the base of the western continental slope (Fig. 1). In 1987, the SA concentration in the deep waters of the western Ionian was $6.3 \mu \mathrm{mol} \mathrm{Si} \mathrm{kg}{ }^{-1}$, south of Crete $9.1 \mu \mathrm{mol} \mathrm{Si} \mathrm{kg}{ }^{-1}$ and in the eastern Levantine $10.7 \mu \mathrm{mol} \mathrm{Si} \mathrm{kg}{ }^{-1}$ (Fig. 2a). This represents an increase of $4.4 \mu \mathrm{mol} \mathrm{Si} \mathrm{kg}{ }^{-1}$ across the basin in the known direction of ADW flow (Roether and Schlitzer, 1991). The EMT event, which changed the deep circulation of the EMS, also altered the depth distribution of silicic acid. By 1999 its effect was already observed in the deep waters of the EMS as a layer of younger water of Aegean origin with lower silicic acid content (Fig. 2) (Kress et al., 2003). The concentration of silicic acid south of Crete was $7.6 \mu \mathrm{mol} \mathrm{Si} \mathrm{kg}{ }^{-1}, 8.6 \mu \mathrm{mol} \mathrm{Si} \mathrm{kg}{ }^{-1}$ in the eastern Levantine and $8.3 \mu \mathrm{mol} \mathrm{Si} \mathrm{kg}{ }^{-1}$ in the western Ionian.

\subsection{Silicic acid in porewaters}

Figure 3 shows the concentration gradient of silicic acid in the porewaters as a function of depth for the upper $10 \mathrm{~cm}$ of all the cores taken by Jones (1977) within the EMS (Table 1). Stations 6,7 and 8 have a relatively shallow and constant gradient which was rather different from the profile from station 10. These stations are from the deep EMS in areas where
Crombet et al. (2011) found no evidence of increased diatom presence in the overlying water column. The upper porewater SA from cores 6, 7 and 8 have been used to calculate an average SA flux from the sediment in the basin to EMS deep waters. The SA concentration gradient driving this flux through the sediment-water interface was calculated using the interstitial [SA] from the uppermost slice of sediment on each core. A linear approximation was used. The deepest water column [SA] on a hydrocast at the same station as the core (or at a nearby station) was assumed to equal the [SA] at the sediment-water interface. To obtain the estimated gradient, that $[\mathrm{SA}]$ was then subtracted from the interstitial [SA] in the uppermost slice, and the difference divided by one-half of the thickness of the slice. The average gradient by this method was $35.8 \mu \mathrm{Mcm}^{-1}$. This value is probably a slight underestimate of the actual average gradient at the sedimentwater interface. Interstitial [SA] profiles tend to show upward curvature near the sediment-water interface, suggesting that a non-linear approximation (e.g. Fanning and Pilson, 1974) might be used to obtain the gradient at the interface. The equation for an upward-curved [SA] distribution would yield a higher gradient at the interface than a linear approximation for the same distribution. Thus fluxes calculated with the average [SA] gradient for the EMS may be somewhat low.

As might be expected given the paucity of biogenic silica contributions to the EMS, the average value of the EMS [SA] gradient $\left(35.8 \mu \mathrm{M} \mathrm{cm}^{-1}\right)$ was smaller than similarly obtained gradients from areas with established contributions of diatomaceous productivity: the Antarctic (up to $1450 \mu \mathrm{M} \mathrm{cm}^{-1}$; Fanning, unpublished data), the Gulf of Mexico $\left(124 \mu \mathrm{M} \mathrm{cm}^{-1}\right)$ (Schink et al., 1974), the equatorial Pacific ( $45 \mu \mathrm{M} \mathrm{cm}^{-1}$; calculated from Hurd, 1973) or the Cariaco trench $\left(52 \mu \mathrm{M} \mathrm{cm}^{-1}\right)$ (Fanning and Pilson, 1972). It is also somewhat lower than station 10 , which is a location where diatoms have been found in the overlying water column (Ignatiades et al., 2009; Psarra et al., 2000).

The SA flux through the sediment-water interface was then calculated assuming only molecular diffusion. This was considered reasonable both because of the nature of the sediments, which are deep-sea sediments where bioirrigation was not expected to be a significant process, and because of the shape of the silicic acid profiles, which showed no evidence of being modified by depth-dependent bioirrigation. The molecular diffusion coefficient for silicic acid in seawater measured at $25^{\circ} \mathrm{C}$ is $1 \times 10^{-5} \mathrm{~cm}^{2} \mathrm{~s}^{-1}$ (Wollast and Garrels, 1971). Correcting this for temperature using the Stokes-Einstein relationship $\left(T=13^{\circ} \mathrm{C}\right.$ for $\mathrm{ADW})=0.7 \times 10^{-5} \mathrm{~cm}^{2} \mathrm{~s}^{-1}$. This was then corrected for porosity and tortuosity using Eq. 1 (Berner, 1971):

$D_{\mathrm{s}}=D_{\mathrm{SW}}^{13} \rho \theta^{-2}$.

The average porosity for the upper centimetre of cores was 0.71 , and using a tortuosity of 1.15 resulted in a calculated $D_{\mathrm{s}}=3.8 \times 10^{-6} \mathrm{~cm}^{2} \mathrm{~s}^{-1}$. 


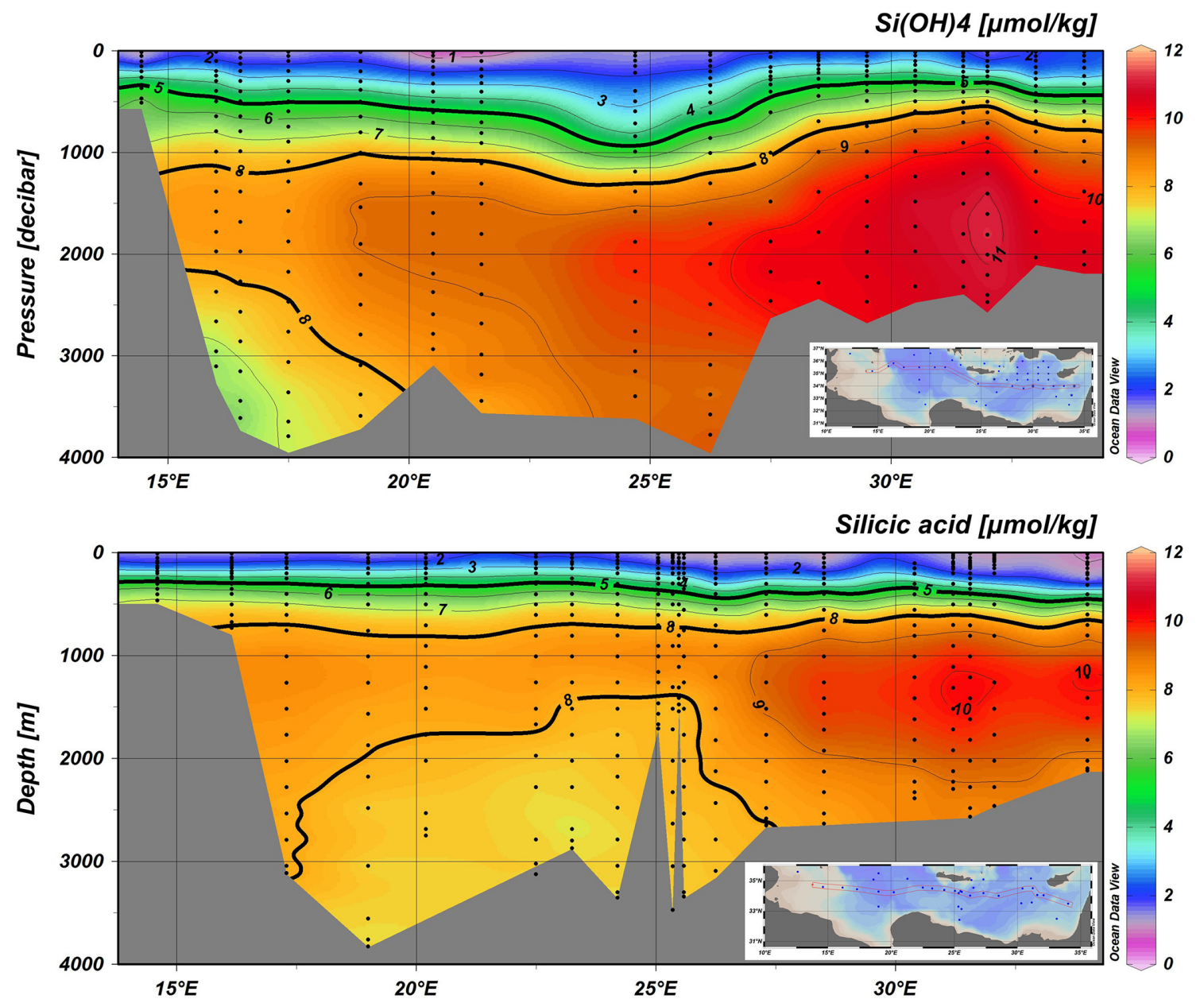

Figure 2. $\mathrm{X}$ section of silicic acid from the western Ionian Sea close to the location of Adriatic deep-water formation in the southern Adriatic to the eastern Levantine Sea. (a) X section measured in 1987 and showing the silicic acid distribution before the EMT increasing from $6.3 \mu \mathrm{mol} \mathrm{Si} \mathrm{kg}{ }^{-1}$ in the western Ionian to $10.7 \mu \mathrm{mol} \mathrm{Si} \mathrm{kg}{ }^{-1}$ in the eastern Levantine (Data from Schlitzer et al., 1991 and Nellen et al., 1996). (b) X section measured in 1999 after EMT event and showing the presence of newer deep water formed in the Aegean and advected into the deep water of the basin (Data from Kress et al., 2003).

The flux of silicic acid out of the sediment, $F_{\mathrm{s}}$, calculated by Fick's 1st law was

$F_{\mathrm{S}}=-\mathrm{d} C / \mathrm{d} z \times D_{\mathrm{s}}$.

Substituting in Eq. (2) gives

$$
\begin{aligned}
& F_{\mathrm{s}}=-\left(35.8 \mu M \mathrm{~cm}^{-1}\right) \times\left(3.8 \times 10^{-6} \mathrm{~cm}^{2} \mathrm{~s}^{-1}\right) \\
& =-4.3 \times 10^{10} \mu \mathrm{mol} \mathrm{Si} \mathrm{km}{ }^{-2} \mathrm{yr}^{-1} .
\end{aligned}
$$

This flux is similar to though somewhat lower than the fluxes measured in the $\mathrm{S}$ Adriatic $\left(6.6 \times 10^{10} \mu \mathrm{mol} \mathrm{Si} \mathrm{km}{ }^{-2} \mathrm{yr}^{-1}\right)$ from areas where diatoms are known to be present in the overlying waters (Giordani et al., 2002). This flux also similar to that calculated using core 10 $\left(6.4 \times 10^{10} \mu \mathrm{mol} \mathrm{Si} \mathrm{km}{ }^{-2} \mathrm{yr}^{-1}\right)$, which was the location where there were suggested to be diatoms in the overlying waters. Using an area of $1337 \times 10^{9} \mathrm{~m}^{2}$ (which is the area of the Ionian and Levantine basins together and is the $\mathrm{X}$ section shown in Fig. 2) the total silicic acid flux into the EMS was $57.2 \times 10^{9} \mathrm{~mol} \mathrm{yr}^{-1}$.

\section{Discussion}

\subsection{Distribution of silicic acid in the EMS prior to Eastern Mediterranean Transient}

$\mathrm{X}$-sectional profiles across the EMS show no change in SA content $\left(\sim 1 \mu \mathrm{mol} \mathrm{Si} \mathrm{kg}{ }^{-1}\right)$ in the photic zone $(0-200 \mathrm{~m}$; Fig. 2a and b) from the stations nearest to the Straits of Sicily, the source of inflowing surface water from the western Mediterranean (WMS) to the easternmost Levantine basin. Furthermore there is no evidence of seasonal changes in concentration (Kress and Herut, 2001). The inflowing water from the WMS has a concentration of $\sim 1 \mu$ mole $\mathrm{Si} \mathrm{kg}^{-1}$, 


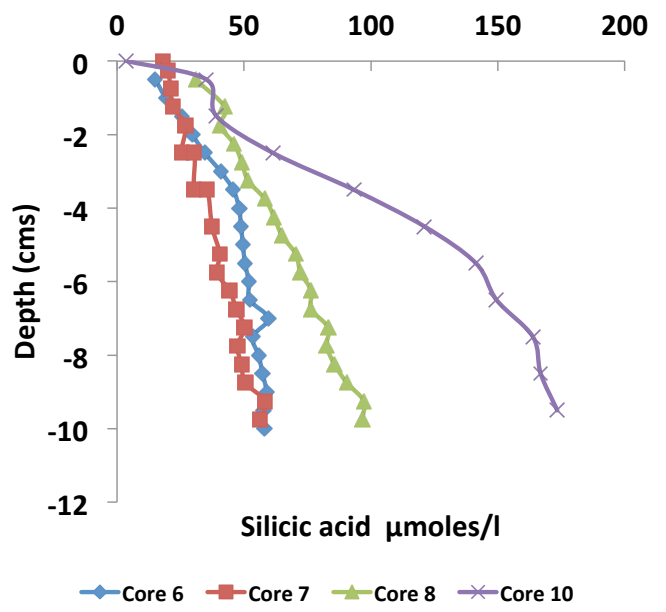

Figure 3. Porewater profiles of silicic acid with depth from a series of porewater profiles in the deep water across the eastern Mediterranean Sea sampled in 1975 (Jones, 1977).

which is not altered by uptake due to diatoms in the surface waters because there are insignificant numbers of diatoms (Ignatiades et al., 2009; Psarra et al., 2000). In those locations where diatoms are known to exist, such as at the Mediterranean front (Crombet et al., 2011), it is possible to see decreases in SA due to diatom uptake.

The concentration of silica in the 200-500 m layer, which is the intermediate water exported from EMS, was 1$8 \mu \mathrm{mol} \mathrm{Si} \mathrm{kg}{ }^{-1}$ in summer (September-October) and somewhat higher in winter $\left(1-10 \mu \mathrm{mol} \mathrm{Si} \mathrm{kg}{ }^{-1}\right.$, Fig. 4, Table 2). This intermediate layer flows out of the EMS due to its unusual anti-estuarine circulation with a residence time of $\sim 8$ yr (Van Cappellen et al., 2014). It is the reason why the $\mathrm{N}$ and $\mathrm{P}$ concentrations are so low compared to other areas of the global ocean. It is likely that the SA content in the EMS is unusually low for the same reason. Prior to the formation of the EMT, there was a simple increase in silicic acid in the deep water of the eastern Mediterranean from west to east. Silicic acid increased from $6.3 \mu \mathrm{mol} \mathrm{Si} \mathrm{kg}{ }^{-1}$ in the western Ionian Sea to $10.7 \mu \mathrm{mol} \mathrm{Si} \mathrm{kg}{ }^{-1}$ in the eastern Levantine basin (Fig. 2), which also corresponds to the direction of water flow of ADW (Roether and Schlitzer, 1991). The "initial" silicic acid observed in the western Ionian Sea derives from deep-water formation in the southern Adriatic Sea. Unusually in the EMS, compared with most areas of the ocean, deep water is formed simultaneously with the annual phytoplankton bloom (Krom et al., 2013). The best estimate for dissolved silicic acid concentration in winter in the area of the $\mathrm{S}$ Adriatic where ADW forms is $3 \mu \mathrm{mol} \mathrm{Si} \mathrm{kg}{ }^{-1}$ (Zavatarelli et al., 1998). In addition there is biogenic particulate silica (BSi) derived from diatoms growing during the phytoplankton bloom in the S Adriatic in winter. Boldrin et al. (2002) measured the total suspended matter during the annual phytoplankton bloom as $0.88 \mathrm{mg} \mathrm{L}^{-1}$ in the $\mathrm{S}$ Adriatic close to
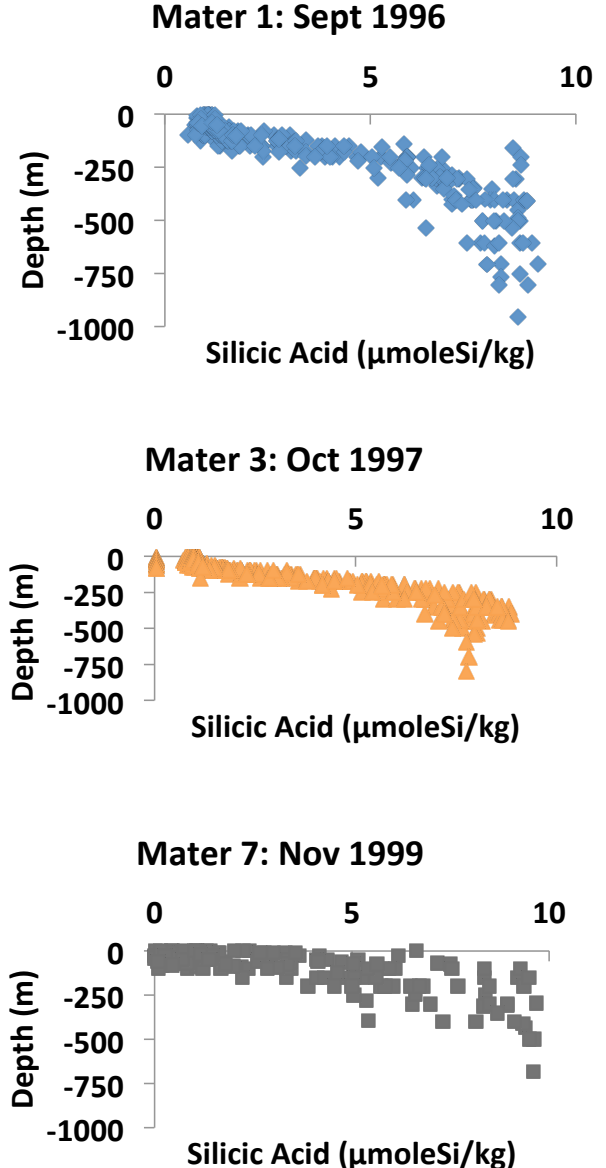

Figure 4. Vertical distribution of dissolved silicic acid in the water column of a series of stations across the Straits of Sicily sampled as part of the MTP-MATER programme (1996-1999) (Data from Lavezza et al., 2011).

the area of Adriatic deep-water formation. At a trap located at $150 \mathrm{~m}$ depth, they found that BSi represents $22 \%$ of the total material flux. If we assume that the downward flux has the same proportion of $\mathrm{BSi}$ as the plankton on the water column, then the concentration in the water column is

$(0.88 \times 0.22) \times 1000 / 60$, i.e. $3.2 \mu \mathrm{mol} \mathrm{Si} \mathrm{kg}^{-1}$.

Thus the initial silicic acid value of $6.3 \mu \mathrm{mol} \mathrm{Si} \mathrm{kg}{ }^{-1}$ in the western Ionian deep water is preformed silicic acid plus BSi present in the downwelled ADW, which dissolved rapidly. This is considered reasonable since the deep water in the EMS is not only low in silicic acid concentration compared to other deep water locations in the ocean but is also relatively warm $\left(\sim 13^{\circ} \mathrm{C}\right)$ (Roether et al., 2007). Though both factors increase the rate of $\mathrm{BSi}$ dissolution, temperature is considered most important (DeMaster, 2004).

As the deep water flows to the east, the total silicic acid increases in concentration by $4.4 \mu \mathrm{mol} \mathrm{Si} \mathrm{kg}{ }^{-1}$. This increase is considerably larger than the observed changes in nitrate in the deep water $\left(\sim 0.5 \mu \mathrm{mol} \mathrm{N} \mathrm{kg}^{-1}\right)$, which itself is larger 
than the observed change in phosphate $\left(0.05 \mu \mathrm{mol} \mathrm{P} \mathrm{kg}^{-1}\right.$; Krom et al., 2013). These differences correspond to known differences in recycling efficiency of nutrients in the water column in the EMS and elsewhere. In the EMS it has been shown that $\mathrm{P}$ is very efficiently recycled in the upper layers of the water probably because of the extreme P-starved nature of the system (Krom et al., 2005; Thingstad et al., 2005). Nitrogen is recycled somewhat less rapidly, but both are recycled faster than biogenic silica is converted into dissolved silicic acid (DeMaster, 2004).

In order to calculate the total amount of silicic acid supplied to the deep water, we use the definition of the eastern Mediterranean used by Van Cappellen et al. (2014) of the Ionian plus Levantine basin where there is a relatively simple flow of deep water from its source in the southern Adriatic to the far eastern Levantine basin (prior to the EMT). This part of the EMS has a total area of $1337 \times 10^{9} \mathrm{~m}^{2}$ and a total volume below $500 \mathrm{~m}$ of $17 \times 10^{14} \mathrm{~m}^{3}$. Roether and Schlitzer (1991) suggest that the water column below $1200 \mathrm{~m}$ is well mixed, which is the approximate depth of the base of the siliciacline. The total volume below $1200 \mathrm{~m}$ is $7.64 \times 10^{14} \mathrm{~m}^{3}$. Thus the total increase in silicic acid below $1200 \mathrm{~m}$ is $7.6 \times 10^{14} \times 4.4 \mu \mathrm{mol} \mathrm{Si} \mathrm{L}{ }^{-1}=33.6 \times 10^{11} \mathrm{~mol} \mathrm{Si}$.

In addition the volume between 500 and $1200 \mathrm{~m}$ has increased silicic acid, which is supplied from below by eddy diffusion. Here we assume that the siliciacline is linear and thus the average change in silicic acid is $2.25 \mu \mathrm{mol} \mathrm{Si} \mathrm{L}{ }^{-1}$. The total amount of silicic acid supplied to the deep waters of the EMS was $33.6 \times 10^{11} \mathrm{~mol} \mathrm{Si}+9.36 \times 10^{14} \times 2.25 \mu \mathrm{mol}$ $\mathrm{Si} \mathrm{L}^{-1}=54.6 \times 10^{11} \mathrm{~mol} \mathrm{Si}$.

This change in silicic acid concentration takes place as the deep water flows from the southern Adriatic/western Ionian to the far SE Levantine basin. Roether and Schlitzer (1991) calculated the residence time of ADW to be 100-126 yr based on chlorofluorocarbon and tritium values. Using this calculated residence time of deep water in the EMS, the silicic acid content increases at a rate of

$54.6 \times 10^{11} \mathrm{~mol} \mathrm{Si}$ in $126-100 \mathrm{yr}=43-54 \times 10^{9} \mathrm{~mol} \mathrm{Si} \mathrm{yr}^{-1}$.

This is similar to, though slightly lower than, the calculated flux of silicic acid from the porewaters of the sediment underlying the EMS deep waters $\left(57.2 \times 10^{9} \mathrm{~mol} \mathrm{Si} \mathrm{yr}^{-1}\right)$. It is thus possible to explain the observed increase in dissolved silicic acid in the deep water to be mainly a result of dissolution of particulate silicic acid in the sediment and flux into the deep water (within $\pm 20 \%$ ). If there is silicic acid produced by dissolution in the water column as is found to be important in many areas of the world's oceans (DeMaster, 2004), it is relatively small compared to the sediment source.

\subsection{Silica budget calculations for the EMS}

In this calculation, we use the best available estimates for the external dissolved Silicic acid into and out of the eastern Mediterranean basin for exchange through the Straits of Sicily, riverine and submarine groundwater input, atmospheric input and flux of silicic acid from porewaters (Table 4). We include BSi (and LSi) supplied externally to the basin as important parts of the biologically reactive silica budget that were not included in previous budgets (Ribera d'Alcalà et al., 2003; Schink, 1967). An indication that such an approach which includes BSi and LSi is justified is the calculation used to explain the observed increase in silicic acid in the deep water across the EMS which required both dissolved silicic acid and BSi in the descending ADW to be combined to create the observed initial silicic acid in the western Ionian sea.

\subsubsection{Fluxes through the Straits of Sicily}

The silicic acid flux through the Straits of Sicily was calculated using water flux determined by Astraldi et al. (1999) together with the measured silicic acid concentration data from the Mediterranean Targeted Project II-Mass Transfer and Ecosystem Response (MTPII-MATER) data set (Lavezza et al., 2011). Although Astraldi et al. (1999) present the flux of water out of the eastern Mediterranean through the Tunisian and Sicilian passages separately, in this calculation only the summed monthly flux for both passages together was used. This was because the flux for each passage was similar $\left(0.54 \pm 0.58\right.$ and $\left.0.55 \pm 0.17 \times 10^{6} \mathrm{~m}^{3} \mathrm{~s}^{-1}\right)$. In order to maintain the salinity balance of the basin, there must be $4 \%$ more water flowing into the eastern Mediterranean at the Straits of Sicily than flowing out (Bethoux, 1980). This value is similar to the estimate of total outflow through the Straits of Sicily of $1.2 \times 10^{6} \mathrm{~m}^{3} \mathrm{~s}^{-1}$ based on salinity balance. The calculated flow through the Straits of Sicily into the eastern Mediterranean was $1.13 \times 10^{6} \mathrm{~m}^{3} \mathrm{~s}^{-1}$ with an outflow of $1.08 \times 10^{6} \mathrm{~m}^{3} \mathrm{~s}^{-1}$. Astraldi et al. (1999) found that there are systematic seasonal changes in both water flux and the depth of the upper layer of the outflowing Levantine Intermediate Water (LIW) through the Straits of Sicily. The flux is higher in winter than in summer by approximately $50 \%$. All the water which flows into the eastern basin is surface water with the nutrient characteristics of water within the photic zone. In winter (November-March) only intermediate and deep water below $200 \mathrm{~m}$ flows out of the eastern Mediterranean (Astraldi et al., 1999). For the rest of the year the outflowing water is much closer to the surface. Two calculations were carried out for this budget (Table 3). In the first, the total annual water flow was used: $1.13 \mathrm{~Sv}$ inflow and $1.08 \mathrm{~Sv}$ outflow. In the second calculation it was assumed that the monthly rate of flow was 1.5 times higher in winter than in summer. The MTP-MATER silicic acid data set - which was measured in September 1996 (MATER 1), October 1997 (MATER 3) and 
November 1999 (MATER 7) - was used to calculate the concentration of silicic acid (and hence the annual flux) through the Straits of Sicily (Lavezza et al., 2011; Fig. 4). The data from September and October (Fig. 4a and b, Table 2) are similar to profiles measured elsewhere in the EMS in the summer (Kress and Herut, 2001), with a depth-averaged silicic acid concentration of $1.2 \mu \mathrm{mol} \mathrm{Si} \mathrm{kg}-1$ in the upper $100 \mathrm{~m}$, which is the layer flowing into the EMS (Astraldi et al., 1999). Concentrations increased with depth to a relatively constant value of $6.2 \mu \mathrm{mol} \mathrm{Si} \mathrm{kg}{ }^{-1}$ (depth-averaged) similar to values found in the western Ionian sea (Figs. 2 and 4).

In addition to silicic acid fluxing through the Straits of Sicily there is also BSi. Crombet et al. (2011) found, in July $2009,0.25 \mu \mathrm{mol} \mathrm{BSi} \mathrm{kg}{ }^{-1}$ in the upper (inflowing) water column with insignificant amounts in the deeper (outflowing) water. The Straits of Sicily are relatively shallow and are known to have considerable turbulence and eddies (Astraldi et al., 1999). It is thus likely to be a location of nutrient upwelling which elsewhere in the EMS is known to result in diatom growth (Crombet et al., 2011; Siokou-Frangou et al., 2010). It is however likely that the amount of BSi in the upper water column in July is a minimum for the year. In general, primary productivity in July in the EMS is close to its annual minimum (Krom et al., 2013). Here we assume that the annual average of BSi together with upwelled silicic acid not yet consumed by diatoms into BSi is $1.0 \mu \mathrm{mol} \mathrm{Si} \mathrm{kg}{ }^{-1}$. This represents a relatively high estimate for the BSi flowing into the EMS. Using this value, the net flux of silicic acid through the straits was $140 \times 10^{9} \mathrm{~mol} \mathrm{Si} \mathrm{yr}^{-1}$ (Table 3).

However the silicic acid measured in November 1999 (Fig. 4c) showed considerate scatter in the upper $200 \mathrm{~m}$ of the water column, with an average value of $4.25 \mu \mathrm{mol} \mathrm{Si} \mathrm{kg}{ }^{-1}$. November is known, from remote sensing data and direct measurements, to be the beginning of deep winter mixing in the EMS and the start of the annual phytoplankton bloom (Krom et al., 2013; Patara et al., 2009). It is reasonable to suggest that this increased silicic acid was due to this deep winter mixing before most of the silicic acid was taken up by diatoms. No BSi was measured during the MATER cruises. Therefore in an alternative calculation we assume that the net silicic acid supplied to the upper $200 \mathrm{~m}$ in November was typical of the winter supply from below and allow this net concentration of silicic acid to be advected into the EMS with no BSi. In practice it does not matter whether this silicic acid was actually advected as dissolved silicic acid or was taken up as diatoms and advected as BSi. It is assumed that this winter flux occurred for 6 months and the summer flux with BSi of $1 \mu \mathrm{mol} \mathrm{Si} \mathrm{kg}{ }^{-1}$ occurred for 6 months. We also use the higher winter flow rate as determined by Astraldi et al. (1999), where the winter flow rate represents $60 \%$ of the annual water flux and summer flow rate $40 \%$. Using these assumptions the net silica outflow from the basin was $127 \times 10^{9} \mathrm{~mol} \mathrm{Si} \mathrm{yr}^{-1}$ (Table 3). We use this higher influx of silica in our total budget estimate (Table 4).

\subsubsection{Sediment as a source and sink of silicic acid}

The calculated flux of silicic acid from the offshore sediments into the water column was estimated as $57 \times 10^{9} \mathrm{~mol} \mathrm{Si} \mathrm{yr}^{-1}$. We argue here that this silicic acid is formed dominantly by the diagenetic alteration of aluminosilicate minerals derived from dust, volcanic ash and other terrigenous sources (DeMaster, 2004; Fanning and Schink, 1969; Koning et al., 2002) and thus represents an additional external source. There are several active volcanoes in the EMS basin (e.g. Santorini), and it is known that there are observable ash layers found within the sediment. Even in the N Atlantic (the Iberian Shelf and the Angolan basin), where diatoms are abundant and the dissolved silicic acid in the deep water is much higher, an average of $50 \%$ of the silicic acid formed in the porewaters and advected out is derived from the diagenesis of aluminosilicate minerals (Koning et al., 2002). If BSi were a major component in the particulate matter reaching the sediment in cores $6-8$, that phase would be expected to dissolve more rapidly than lithogenically derived SA and would create a convex upward shape, possibly similar to the profile of core 10 (which is not included in the regional flux calculations). The upper porewater profiles for cores 6-8 are linear and have a low gradient, which is consistent with being derived from mineral weathering. Given that it is known that for large areas of the EMS there are relatively few diatoms (Ignatiades et al., 2009) and that the deep waters have very low SA concentration compared to most deep parts of the ocean, this assumption is considered reasonable. An alternative source for this SA might be a flux from the dissolution of BSi in the upper sapropel layer which is present at 20-30 cm depth (e.g. van Santvoort et al., 1996), below our porewater data. For the purposes of this budget this source would also be new silica into the basin. However no data are presently available on the long-term burial flux of biogenic or lithogenic Si in the eastern Mediterranean (Koning et al., 2002). We assume that no significant amounts of silica are permanently lost from the system by sedimentation. These assumptions clearly need to be tested by field measurements.

\subsubsection{Riverine inputs}

Ludwig et al. (2009) estimated the average flux of SA supplied to the EMS by riverine input between 1963 and 1998 as $23 \times 10^{9} \mathrm{~mol} \mathrm{Si} \mathrm{yr}^{-1}$. Although there has been some variation in SA input over the time period considered (from 19 to $27 \times 10^{9} \mathrm{~mol} \mathrm{Si} \mathrm{yr}^{-1}$ with a standard deviation of $\sim 10 \%$ ), it is much less variable than inorganic $\mathrm{N}$ and $\mathrm{P}$ because, unlike them, SA is not considered a major pollutant. However in their calculation Ludwig et al. (2009) only included dissolved SA. Conley (1997) showed that measurement of silicic acid alone underestimates the global flux of silica from rivers to the ocean because it does not include BSi. Laruelle et al. (2009) estimate a total global flux of riverine dissolved silicic acid to be $6.2 \mathrm{Tmol} \mathrm{Si} \mathrm{yr}^{-1}$ and a flux of 
Table 2. Table showing the depth-averaged concentration of dissolved silicate (in $\mu$ mol kg-1) measured for the series of stations across the Straits of Sicily sampled during the MATER-MTP cruises between 1996 and 1999 (data were obtained from Lavezza et al., 2011).

\begin{tabular}{lll}
\hline $\begin{array}{l}\text { Cruise name, time of sampling } \\
\text { and number of stations averaged } \\
\text { in brackets }\end{array}$ & $\begin{array}{l}\text { Depth-averaged concentration of } \\
\text { SA in layer flowing into the } \\
\text { EMS; depth of layer in brackets }\end{array}$ & $\begin{array}{l}\text { Depth averaged concentration of } \\
\text { SA in the layer flowing out of the } \\
\text { EMS }\end{array}$ \\
\hline MATER 1; Sep 1996 (24) & $1.18(0-100 \mathrm{~m})$ & $6.24(>100 \mathrm{~m})$ \\
MATER 3; Oct 1997 $(17)$ & $1.22(0-100 \mathrm{~m})$ & $6.17(>100 \mathrm{~m})$ \\
MATER 7; Nov 1999 $(12)$ & $4.24(0-100 \mathrm{~m})$ & $7.66(>200 \mathrm{~m})$
\end{tabular}

Table 3. Table of calculated fluxes of silicic acid and BSi through the Straits of Sicily; see the text for detailed information of the assumptions made in each particular calculation. The values in bold were used in the total silica budget for the EMS (Table 4). All fluxes in units of $10^{9} \times \mathrm{mol} \mathrm{Si} \mathrm{yr}^{-1}$

\begin{tabular}{|c|c|c|c|c|c|}
\hline Chemical species & $\begin{array}{l}\text { Inflow } \\
\text { silicic acid }\end{array}$ & $\mathrm{BSi}$ & Net inflow & $\begin{array}{l}\text { Outflow } \\
\text { silicic acid }\end{array}$ & Net flux \\
\hline $\begin{array}{l}\text { Total annual flux assuming summer values for } \\
\text { silicic acid and an average of } 1 \mu \mathrm{mol} B S i L^{-1} \\
\text { in the photic zone for the entire year. }\end{array}$ & 47 & 39 & 85 & 225 & 140 \\
\hline $\begin{array}{l}\text { Calculated summer flux ( } 6 \text { months) using sum- } \\
\text { mer values for silicic acid and } 1 \mu \text { mol BSi } \mathrm{L}^{-1} \\
\text { with } 40 \% \text { of the total annual flow (Astraldi } \\
\text { et al., 1999). }\end{array}$ & 19 & 16 & 34 & 90 & 56 \\
\hline $\begin{array}{l}\text { Calculated winter ( } 6 \text { months) using winter (Nov } \\
\text { 1999) silicic acid values and with } 60 \% \text { of the } \\
\text { total annual flow (Astraldi et al., 1999). }\end{array}$ & 103 & & 103 & 174 & 71 \\
\hline $\begin{array}{l}\text { Calculated total annual fluxes summing winter } \\
\text { and summer values. }\end{array}$ & 121 & 16 & 137 & 264 & 127 \\
\hline
\end{tabular}

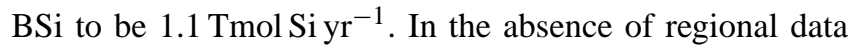
(e.g. river $\mathrm{Po}$ ) we use this global ratio to correct the riverine flux of $23 \times 10^{9} \mathrm{~mol} \mathrm{Si} \mathrm{yr}^{-1}$ to a total riverine input of $27 \times 10^{9} \mathrm{~mol} \mathrm{Si} \mathrm{yr}^{-1}$.

\subsubsection{Submarine groundwater flux (SGW)}

A potentially important source of nutrient input into the EMS is submarine groundwater discharge. Large areas of the coastal Mediterranean are made from chalk and other porous and/or permeable rocks. Laruelle et al. (2009) estimate that the submarine discharge of freshwater into the Mediterranean represents $25 \%$ of the total riverine input. It is known that SGW contains elevated amounts of dissolved nutrients, including silicic acid. They estimate a global average of $200 \mu \mathrm{mol} \mathrm{Si} \mathrm{kg}{ }^{-1}$, which is in the mid-range of a specific study on SGW carried out at Dor on the Israeli coast (Weinstein et al., 2011). Taken together this represents a flux of $9.7 \mathrm{~mol} \mathrm{Si} \mathrm{yr}^{-1}$ calculated as $25 \%$ of total riverine water flow $\times 200 \mu \mathrm{mol} \mathrm{Si} \mathrm{kg}{ }^{-1}$.

\subsubsection{Atmospheric flux}

Saharan dust is a major source of particulate matter to the offshore EMS. This dust falls through the water column relatively rapidly and becomes a major component of aluminosilicates in the sediment which undergo chemical weathering. Thus it is only the short-term (water column) dissolution of silicic acid which is relevant to this budget calculation.

In a short-term dissolution experiment (48h) dust collected from Crete (and used in a MESOAQUA dust addition experiment) released $25 \mathrm{nmol} \mathrm{Si} \mathrm{mg}^{-1}$ dust (B. Herut, personal communication, 2013).

$$
\begin{aligned}
& \text { Atmospheric Flux }=31 \mathrm{~g} \mathrm{~m}^{-2} \mathrm{yr}^{-} \times 25 \mu \mathrm{mol} \mathrm{Si} \mathrm{g}^{-1} \\
& =775 \mu \mathrm{mol} \mathrm{m}^{-2} \mathrm{yr}^{-1}
\end{aligned}
$$

Using a total area of $1337000 \mathrm{~km}^{2}$ this converts to $=1.0 \times 10^{9} \mathrm{~mol} \mathrm{Si} \mathrm{yr}^{-1}$.

The atmospheric flux was thus a relatively small direct source of silica to the EMS, though with potentially large variability since it is known that Saharan dust is very inhomogeneous. Some sources of desert dust are known to have higher and potentially much higher fractions of opaline silica. In particular the Bodele depression - which is the single largest source of Saharan dust at present, particularly to the 


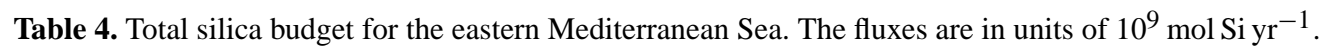

\begin{tabular}{|c|c|c|}
\hline \multicolumn{3}{|c|}{ Silica flux into the eastern Mediterranean basin } \\
\hline Source of silica & Flux & Comment \\
\hline Straits of Sicily - dissolved silicic acid & 121 & $\begin{array}{l}\text { Calculated using winter (Nov 1999) SA and water flow } \\
\text { data for } 6 \text { months and summer (Sept 1997) silicic acid } \\
\text { and flow data for } 6 \text { months (Table 3). }\end{array}$ \\
\hline Straits of Sicily - BSi & 16 & $\begin{array}{l}\text { Using summer flow rate }(<100 \mathrm{~m}) \text { and } 1 \mu \mathrm{mol} \mathrm{L}^{-1} \text { dur- } \\
\text { ing summer } 6 \text { months (Table } 3) \text {. }\end{array}$ \\
\hline Riverine input - dissolved silicic acid and BSi & 27 & $\begin{array}{l}\text { Ludwig et al. (2009) corrected using global values for } \\
\text { BSi input from Laruelle et al. (2009). }\end{array}$ \\
\hline Submarine groundwater flux & 9.7 & $\begin{array}{l}\text { Using estimates for freshwater flow into the EMS and } \\
\text { silicic acid values from Laruelle et al. (2009) and Wein- } \\
\text { stein et al. (2011). }\end{array}$ \\
\hline Sediment porewater flux & 57 & $\begin{array}{l}\text { Calculated value for silicic acid flux assuming all is } \\
\text { the result of diagenetic dissolution from aluminosilicate } \\
\text { minerals. }\end{array}$ \\
\hline Atmospheric Saharan dust input - BSi & 1 & $\begin{array}{l}\text { Based on total BSi measured in Saharan dust samples } \\
\text { (Krom, unpubl. data). }\end{array}$ \\
\hline Total input & 232 & \\
\hline \multicolumn{3}{|c|}{ Silica flux out of the eastern Mediterranean basin } \\
\hline Straits of Sicily - silicic acid & 264 & $\begin{array}{l}\text { Measured average silicic acid }>100 \mathrm{~m} \text { in summer and }> \\
200 \mathrm{~m} \text { in winter. Astraldi et al. (1999) for flow data and } \\
\text { MTP-MATER data for silicate (Table 3). }\end{array}$ \\
\hline Sediment burial flux & 0 & \\
\hline Total outflow & 264 & \\
\hline $\begin{array}{l}\text { Net export flux from the eastern Mediterranean } \\
\text { basin }\end{array}$ & 32 & \\
\hline
\end{tabular}

eastern Atlantic -is a diatomite and contains relatively large amounts of opaline silica.

\subsection{Total silica budget for the EMS}

The net flux of dissolved silicic acid flowing out of the EMS at the Straits of Sicily is $\left(121 \times 10^{9} \mathrm{~mol} \mathrm{Si} \mathrm{yr}^{-1}\right)$, is somewhat lower than the lower range of the previous estimate of $157 \times 10^{9} \mathrm{~mol} \mathrm{Si} \mathrm{yr}^{-1}$ by Ribera d'Alcala et al. (2003) because it includes BSi and winter upwelled silicic acid fluxing into the EMS. Here detailed estimates have been made of the silica input from riverine input containing BSi, submarine groundwater flux, sediment porewater flux and atmospheric input. By including these terms, the deficit of silica in much reduced to $32 \times 10^{9} \mathrm{~mol} \mathrm{Si} \mathrm{yr}^{-1}$.

Key to this total budget is the assumption that the dissolution of externally supplied BSi, and the internal weathering of aluminosilicates are important processes in the EMS. Such dissolution is required to explain the initial concentration of dissolved silicic acid in the western Ionian basin, the increase in dissolved silicic acid across the ADW to the southeastern Levantine basin as well as to "close" the total silica budget for the basin. While such dissolution processes are known to occur elsewhere in the ocean (DeMaster, 2004), they are particularly important in the EMS with its low initial concentra- tions of silicic acid, relatively high temperature of deep water and high input of dust and riverine particles.

By contrast, recycling by diatoms appears not to be regionally important. The observed vertical profile in dissolved silicic acid can be explained entirely as a result of the circulation of the EMS, with the surface concentration of silicic acid being derived from surface water advecting in through the Straits of Sicily and the increase in deep water being due to processes during ADW formation in the S Adriatic and the flux of silicic acid from sediments across the basin. That is not to say that there is no internal cycling of silica from diatoms in the EMS. Crombet et al. (2011) showed clearly that there is a measured increase in diatom abundance and a "deep glass forest" where there is nutrient upwelling (i.e. in the Straits of Sicily, the Ionian front and possibly also the Cyprus eddy). There are also diatoms in the permanent coldwater eddies and increased diatom abundance in coastal waters. What is argued here is that the presence of diatoms and recycling from diatoms falling from the photic zone are not required to explain the regional pattern of silicic acid in the offshore EMS.

The remaining deficit in the EMS budget could possibly be explained simply as a result of the errors and assumptions which were made in the principal terms used in constructing 
this silica budget. For example if the BSi in summer were an average of $2.0 \mu$ mole $\mathrm{Si} \mathrm{kg}^{-1}$ instead of the assumed value of $1 \mu$ mole $\mathrm{Si} \mathrm{kg}^{-1}$, the deficit would be eliminated; while if the average concentration of the outflowing water were that measured in September and October $\left(6.2 \mu \mathrm{mol} \mathrm{Si} \mathrm{kg}{ }^{-1}\right)$ rather than the $7.4 \mu \mathrm{mol} \mathrm{Si} \mathrm{kg}{ }^{-1}$ determined in November, there would be a small net accumulation of silica in the EMS. One potentially important process which has not been included in this budget is the effect of silica cycling processes in coastal areas. Recently it was shown that $\mathrm{Si}$ is advected from the shore towards the open sea in the easternmost part of the Mediterranean (Efrati et al., 2013). If silicic acid from diagenesis on the continental shelf is advected from the coastal shelf into the offshore waters, it will represent a new source of silicic acid which will be exported from the basin. A particularly important source for such silicic acid may be the Nile cone and adjacent coastal shelves since it is known that, during the Nile flood (before the closure of the Aswan Dam), there was a major diatom bloom in the offshore region (Halim, 1991). This process could take place either by direct advection of silicic acid into intermediate water or by the export of BSi produced by diatom uptake of silicic acid in surface waters of the shelf being transported offshore and then dropping into the intermediate waters. We recognise that Table 4 represents a preliminary budget and that further targeted measurements need to be made of the major terms in this budget, particularly the annual BSi content in the surface inflowing waters at the Straits of Sicily, the sediment and diagenetic processes in the surficial sediments and riverine inputs.

Acknowledgements. Sandra Lynn Jones measured and evaluated interstitial silica concentrations in the eastern Mediterranean for her graduate thesis. Unfortunately she passed away before the scientific research context was developed that showed how significant her work really was. She was a fine colleague who had a remarkable creativity and will continue to be missed.

Research on this topic by KAF was supported by US National Science Foundation grants GA41200, OCE 74-01480-A02 and OCE-7682416.

Edited by: A. Shemesh

\section{References}

Armbrust, E. V.: The life of diatoms in the world's oceans, Nature, 459, 185-192, 2009.

Astraldi, M., Balopoulos, S., Candela, J., Font, J., Gacic, M., Gasparini, G. P., Manca, B., Theocharis, A., and Tintore, J.: The role of straits and channels in understanding the characteristics of Mediterranean circulation, Prog. Oceanogr., 44, 65-108, 1999.

Bainbridge, A. E.: GEOSECS Atlantic Expedition, Vol. 1, Hydrographic Data 1927-3, National Science Foundation, Washington, DC, 1981 .
Benitez-Nelson, C. R., Bidigare, R. R., Dickey, T. D., Landry, M. R., Leonard, C. L., Brown, S. L., Nencioli, F., Rii, Y. M., Maiti, K., Becker, J. W., Bibby, T. S., Black, W., Cai, W.-J., Carlson, C. A., Chen, F., Kuwahara, V. S., Mahaffey, C., McAndrew, P. M., Quay, P. D., Rappé, M. S., Selph, K. E., Simmons, M. P., and Yang, E. J.: Mesoscale Eddies Drive Increased Silica Export in the Subtropical Pacific Ocean, Science, 316, 1017-1021, 2007.

Berner, R. A.: Principles of Chemical Sedimentology., McGrawHill, New York, 1971.

Bethoux, J. P.: Mean water fluxes across sections in the Mediterranean Sea evaluated on the basis of water and salt budget and of observed salinities, Oceanol. Acta, 3, 79-88, 1980.

Bethoux, J. P., Morin, P., Madec, C., and Gentili, B.: Phosphorus and nitrogen behaviour in the Mediterranean Sea, Deep. Sea Res., 39, 1641-1654, 1992.

Boldrin, A., Miserocchi, S., Rabitti, S., Turchetto, M. M., Balboni, V., and Socal, G.: Particulate matter in the southern Adriatic and Ionian Sea: characterisation and downward fluxes, J. Mar. Syst., 33/34, 389-410, 2002.

Brzezinski, M. A. and Nelson, D. M.: The annual silica cycle in the Sargasso Sea near Bermuda, Deep-Sea Res., 42, 1215-1237, 1995.

Brzezinski, M. A., Krause, J. W., Church, M. J., Karl, D. M., Li, B., Jones, J. L., and Updyke, B.: The annual silica cycle of the North Pacific subtropical gyre, Deep-Sea Res., 58, 988-1001, 2011.

Chester, R.: Marine Geochemistry, Blackwell Science, Oxford, 2002.

Conley, D. J.: Riverine contribution of biogenic silica to the oceanic silica budget, Limnol. Oceanogr., 42, 774-777, 1997.

Crombet, Y., Leblanc, K., Quéguiner, B., Moutin, T., Rimmelin, P., Ras, J., Claustre, H., Leblond, N., Oriol, L., and Pujo-Pay, M.: Deep-silicon maxima in the stratified oligotrophic Mediterranean Sea, Biogeosciences, 8, 459-475, doi:10.5194/bg-8-4592011, 2011.

DeMaster, D. J.: The supply and accumulation of silica in the marine environment, Geochim. Cosmochim. Acta, 45, 1715-1732, 1981.

DeMaster, D. J.: The diagenesis of biogenic silica: Chemical transformations occurring in the water column, seabed, and crust, in: Sediments, Diagenesis, and Sedimentary Rocks, edited by: Mackenzie, F. T., Treatise of Geochemistry, Elsevier, 7, 2004.

Dugdale, R. C. and Wilkerson, F. P.: Silicate regulation of new production in the equatorial Pacific upwelling, Nature, 391, 270273, 1998.

Efrati, S., Lehahn, Y., Rahav, E., Kress, N., Herut, B., Gertman, I., Goldman, R., Ozer, T., Lazar, M., and Heifetz, E.: Intrusion of coastal waters into the pelagic eastern Mediterranean: in situ and satellite-based characterization, Biogeosciences, 10, 3349-3357, doi:10.5194/bg-10-3349-2013, 2013.

Fanning, K. A. and Pilson, M. E. Q.: A model for the anoxic zone of the Cariaco Trench, Deep-Sea Res. and Oceanogr. Abstr., 19, 847-863, 1972.

Fanning, K. A. and Pilson, M. E. Q.: The diffusion of dissolved silica out of deep-sea sediments, J. Geophys. Res., 79, 12931297, 1974.

Fanning, K. A. and Schink, D. R.: Interaction of marine sediments with dissolved silica., Limnol. Oceanogr., 14, 59-69, 1969.

Giordani, P., Helder, W., Koning, E., Miserocchi, S., Danovaro, R., and Malaguti, A.: Gradients of benthic-pelagic coupling and car- 
bon budgets in the Adriatic and Northern Ionian Sea, J. Mar. Syst., 33/34, 365-387, 2002.

Halim, Y.: The impact of human alterations of the hydrological cycle on ocean margins, in: Ocean margin processes in Global Change, Dahlem Conferenzen, edited by: Mantoura, R. F. A., Martin, J.-M., and Wollast, R., Chichester, John Wiley \& Sons Ltd., 281-300, 1991.

Huete-Ortega, M., Calvo-Díaz, A., Graña, R., Mouriño-Carballido, B., and Marañón, E.: Effect of environmental forcing on the biomass, production and growth rate of size-fractionated phytoplankton in the central Atlantic Ocean, J. Mar. Syst., 88, 203213, 2011.

Hurd, D. C.: Interactions of biogenic opal, sediment and seawater in the Central Equatorial Pacific, Geochim. Cosmochim. Acta, 37, 2257-2282, 1973.

Ibello, V., Cantoni, C., Cozzi, S., and Civitarese, G.: First basin-wide experimental results on $\mathrm{N}-2$ fixation in the open Mediterranean Sea, Geophys. Res. Lett., 37, L03608, doi:10.1029/2009GL041635, 2010.

Ignatiades, L., Gotsis-Skretas, O., Pagou, K., and Krasakopoulou, E.: Diversification of phytoplankton community structure and related parameters along a large-scale longitudinal east-west transect of the Mediterranean Sea, J. Plankton Res., 31, 411-428, 2009.

Jones, S. L.: Contribution from deep sediments to the dissolved silica in the deep water of the Mediterranean Sea, M.Sc. thesis, University of South Florida, 1977.

Koning, E., Epping, E., and Van Raaphorst, W.: Determining Biogenic Silica in Marine Samples by Tracking Silicate and Aluminium Concentrations in Alkaline Leaching Solutions, Aquat. Geochem., 8, 37-67, 2002.

Krasakopoulou, E., Souvermezoglou, E., Pavlidou, A., and Kontoyannis, H.: Oxygen and nutrient fluxes through the Straits of the Cretan Arc (March 1994-January 1995), Prog. Oceanogr., 44, 601-624, 1999.

Kress, N. and Herut, B.: Spatial and seasonal evolution of dissolved oxygen and nutrients in the Southern Levantine Basin (Eastern Mediterranean Sea): chemical characterization of the water masses and inferences on the N:P ratios, Deep-Sea Res., 48, 2347-2372, 2001.

Kress, N., Manca, B. B., Klein, B., and Deponte, D.: Continuing influence of the changed thermohaline circulation in the eastern Mediterranean on the distribution of dissolved oxygen and nutrients: Physical and chemical characterization of the water masses, J. Geophys. Res., 108, 8109, doi:10.1029/2002JC001397, 2003.

Kress, N., Herut, B., and Gertman, I.: Nutrient distribution in the eastern Mediterranean before and after the transient event, in: Life in the Mediterranean Sea: A look at habitat changes, edited by: Stambler, N., Nova Science Publishers, Inc., 2011.

Kress, N., Gertman, I., and Herut, B.: Temporal evolution of physical and chemical characteristics of the water column in the Easternmost Levantine Basin (Eastern Mediterranean Sea) from 2002-2010, J. Mar. Syst., 135, 6-13, 2014.

Krom, M. D., Kress, N., Brenner, S., and Gordon, L. I.: Phosphorus Limitation of Primary Productivity in the Eastern Mediterranean Sea, Limnol. Oceanogr., 36, 424-432, 1991.

Krom, M. D., Brenner, S., Kress, N., Neori, A., and Gordon, L. I.: Nutrient dynamics and new production in a warm-core eddy from the Eastern Mediterranean Sea, Deep-Sea Res., 39, 467480, 1992.

Krom, M. D., Herut, B., and Mantoura, R. F. C.: Nutrient budget for the Eastern Mediterranean: Implications for phosphorus limitation, Limnol. Oceanogr., 49, 1582-1592, 2004.

Krom, M. D., Woodward, E. M. S., Herut, B., Kress, N., Carbo, P., Mantoura, R. F. C., Spyres, G., Thingstad, T. F., Wassmann, P., Wexels-Riser, C., Kitidis, V., Law, C. S., and Zodiatis, G.: Nutrient cycling in the south east Levantine basin of the eastern Mediterranean: Results from a phosphorus starved system, DeepSea Res., 52, 2879-2896, 2005.

Krom, M. D., Emeis, K. C., and Van Cappellen, P.: Why is the Eastern Mediterranean phosphorus limited?, Prog. Oceanogr., 85, 236-244, 2010.

Krom, M. D., Kress, N., Berman-Frank, I., and Rahav, E.: Past, present and future patterns in the nutrient chemistry of the Eastern Mediterranean, in: The Mediterranean Sea., its history and present challenges, edited by: Goffredo, S. and Dubinsky, Z., Springer, Dordrecht, 2013.

Kruikov, P. A. and Manheim, F. T.: Extraction and investigativetechniques for study of interstitial waters of unconsolidated sediments: a review, in: The Dynamic Environment of the Ocean Floor, edited by: Fanning, K. A. and Manheim, F. T., DC Heath \& Company, Boston, MA, 1982.

Laruelle, G. G., Roubeix, V., Sferratore, A., Brodherr, B., Ciuffa, D., Conley, D. J., Dürr, H. H., Garnier, J., Lancelot, C., Le Thi Phuong, Q., Meunier, J. D., Meybeck, M., Michalopoulos, P., Moriceau, B., Ní Longphuirt, S., Loucaides, S., Papush, L., Presti, M., Ragueneau, O., Regnier, P., Saccone, L., Slomp, C. P., Spiteri, C., and Van Cappellen, P.: Anthropogenic perturbations of the silicon cycle at the global scale: Key role of the land-ocean transition, Global Biogeochem. Cy., 23, GB4031, doi:10.1029/2008GB003267, 2009.

Lascaratos, A., Roether, W., Nittis, K., and Klein, B.: Recent changes in deep water formation and spreading in the eastern Mediterranean Sea: a review, Prog. Oceanogr., 44, 5-36, 1999.

Lavezza, R., Dubroca, L. F. C., Ludicone, D., Kress, N., Herut, B., Civitarese, G., Cruzado, A., Lefèvre, D., Souvermezoglou, E., Yilmaz, A., Tugrul, S., and Ribera d'Alcala, M.: Compilation of quality controlled nutrient profiles from the Mediterranean Sea, doi:10.1594/PANGAEA.771907, 2011.

Ludwig, W., Dumont, E., Meybeck, M., and Heussner, S.: River discharges of water and nutrients to the Mediterranean and Black Sea: Major drivers for ecosystem changes during past and future decades?, Prog. Oceanogr., 80, 199-217, 2009.

Mackenzie, F. T. and Garrels, R. M.: Silica reactivity with seawater, Science, 150, 57-59, 1965.

Marty, J. C., Chiaverini, J., Pizay, M. D., and Avril, B.: Seasonal and interannual dynamics of nutrients and phytoplankton pigments in the western Mediterranean Sea at the DYFAMED time-series station (1991-1999), Deep-Sea Res., 49, 1965-1985, 2002.

Nellen, W., Bettac, W., Roether, W., Schnack, D., Thiel, H., Weikert, H., and Zeitschel, B.: MINDIK (Band II), Reise Nr. 5, 2 January-24 September 1987, METEOR-Berichte, Universitat Hamburg, 96-2, 179 pp., 1996.

Nelson, D. M., Tréguer, P., Brzezinski, M. A., Leynaert, A., and Quéguiner, B.: Production and dissolution of biogenic silica in the ocean: Revised global estimates, comparison with regional 
data and relationship to biogenic sedimentation, Global Biogeochem. Cy., 9, 359-372, 1995.

Patara, L., Pinardi, N., Corselli, C., Malinverno, E., Tonani, M., Santoleri, R., and Masina, S.: Particle fluxes in the deep Eastern Mediterranean basins: the role of ocean vertical velocities, Biogeosciences, 6, 333-348, doi:10.5194/bg-6-333-2009, 2009.

Psarra, S., Tselepides, A., and Ignatiades, L.: Primary productivity in the oligotrophic Cretan Sea (NE Mediterranean): seasonal and interannual variability, Prog. Oceanogr., 46, 187-204, 2000.

Pujo-Pay, M., Conan, P., Oriol, L., Cornet-Barthaux, V., Falco, C., Ghiglione, J. F., Goyet, C., Moutin, T., and Prieur, L.: Integrated survey of elemental stoichiometry $(\mathrm{C}, \mathrm{N}, \mathrm{P})$ from the western to eastern Mediterranean Sea, Biogeosciences, 8, 883-899, 2011, http://www.biogeosciences.net/8/883/2011/.

Ragueneau, O., Tréguer, P., Leynaert, A., Anderson, R. F., Brzezinski, M. A., DeMaster, D. J., Dugdale, R. C., Dymond, J., Fischer, G., François, R., Heinze, C., Maier-Reimer, E., Martin-Jézéquel, V., Nelson, D. M., and Quéguiner, B.: A review of the Si cycle in the modern ocean: recent progress and missing gaps in the application of biogenic opal as a paleoproductivity proxy, Glob. Planet. Change, 26, 317-365, 2000.

Ribera d'Alcalà, M., Civitarese, G., Conversano, F., and Lavezza, R.: Nutrient ratios and fluxes hint at overlooked processes in the Mediterranean Sea, J. Geophys. Res., 108, 8106, doi:10.1029/2002jc001650, 2003.

Roether, W. and Schlitzer, R.: Eastern Mediterranean deep water renewal on the basis of chlorofluoromethane and tritium data, Dynam. Atmos. Oceans, 15, 333-354, 1991.

Roether, W., Manca, B., Klein, B., Bregant, D., Georgopoulos, D., Beitzel, V., Kovacevic, V., and Luchetta, A.: Recent changes in Eastern Mediterranean Deep-Water, Science, 271, 333-335, 1996.

Roether, W., Klein, B., Manca, B. B., Theocharis, A., and Kioroglou, S.: Transient Eastern Mediterranean deep waters in response to the massive dense-water output of the Aegean Sea in the 1990s, Prog. Oceanogr., 74, 540-571, 2007.

Schink, D. R.: Budget for dissolved silica in the Mediterranean Sea, Geochim. Cosmochim. Acta, 31, 987-999, 1967.

Schink, D. R., Fanning, K. A., and Pilson, M. E. Q.: Dissolved silica in the upper pore waters of the Atlantic Ocean floor, J. Geophys. Res., 79, 2243-2250, 1974.

Schlitzer, R., Roether, W., Oster, H., Junghans, H. G., Hausmann, M., Johannsen, H., and Michelato, A.: Chlorofluoromethane and oxygen in the Eastern Mediterranean, Deep-Sea Res., 38, 1531$1551,1991$.
Siokou-Frangou, I., Christaki, U., Mazzocchi, M. G., Montresor, M., Ribera d'Alcalá, M., Vaqué, D., and Zingone, A.: Plankton in the open Mediterranean Sea: a review, Biogeosciences, 7, 1543 1586, doi:10.5194/bg-7-1543-2010, 2010.

Thingstad, T. F., Krom, M. D., Mantoura, R. F. C., Flaten, G. A. F., Groom, S., Herut, B., Kress, N., Law, C. S., Pasternak, A., Pitta, P., Psarra, S., Rassoulzadegan, F., Tanaka, T., Tselepides, A., Wassmann, P., Woodward, E. M. S., Riser, C. W., Zodiatis, G., and Zohary, T.: Nature of Phosphorus Limitation in the Ultraoligotrophic Eastern Mediterranean, Science, 309, 1068-1071, 2005.

Truesdale, V. W. and Smith, C. J.: The automatic determination of silicate dissolved in natural fresh water by means of procedures involving the use of either $[\alpha]$ - or $[\beta]$-molybdosilicic acid, Analyst, 101, 19-31, 1976.

Van Cappellen, P., Powley, H. R., Emeis, K. C., and Krom, M. D. A biogeochemical model for phosphorus and nitrogen cycling in the Eastern Mediterranean Sea (EMS). Part 1. Model development, initial conditions and sensitivity analyses., J. Mar. Syst., in review, 2014.

van Santvoort, P. J. M., de Lange, G. J., Thomson, J., Cussen, H., Wilson, T. R. S., Krom, M. D., and Ströhle, K.: Active postdepositional oxidation of the most recent sapropel (S1) in sediments of the eastern Mediterranean Sea, Geochim. Cosmochim. Ac., 60, 4007-4024, 1996.

Venkatarathnam, K. and Ryan, W. B. F.: Dispersal patterns of clay minerals in the sediments of the eastern Mediterranean Sea, Mar. Geol., 11, 261-282, 1971.

Weinstein, Y., Yechieli, Y., Shalem, Y., Burnett, W. C., Swarzenski, P. W., and Herut, B.: What Is the Role of Fresh Groundwater and Recirculated Seawater in Conveying Nutrients to the Coastal Ocean?, Environ. Sci. Technol., 45, 5195-5200, 2011.

Wollast, R. and Garrels, R. M.: Diffusion coefficient of silica in seawater., Nature Phys. Sci., 229, p. 94, 1971.

Yilmaz, A. and Tugrul, S.: The effect of cold- and warm-core eddies on the distribution and stoichiometry of dissolved nutrients in the northeastern Mediterranean, J. Mar. Syst., 16, 253-268, 1998.

Yogev, T., Rahav, E., Bar-Zeev, E., Man-Aharonovich, D., Stambler, N., Kress, N., Béjà, O., Mulholland, M. R., Herut, B., and Berman-Frank, I.: Is dinitrogen fixation significant in the Levantine Basin, East Mediterranean Sea?, Environ. Microbiol., 13, 854-871, 2011.

Zavatarelli, M., Raicich, F., Artegiani, A., Bregant, D., and Russo, A.: Climatological biogeochemical characteristics of the Adriatic Sea, J. Mar. Syst., 18, 227-263, 1998. 